\title{
Rekayasa Desain Sistem Pemerintahan Presidensial di Indonesia yang Efektif
}

\author{
Hatta Abdi Muhammad $^{1)}$, Ahmad Baidawi ${ }^{2}$ \\ ${ }^{1}$ Prodi Ilmu Politik, Universitas Jambi \\ ${ }^{2}$ Prodi Ilmu Pemerintahan, Universitas Jambi \\ ${ }^{1}$ Hattaabdimuhammad@gmail.com, ${ }^{2}$ ahmad.baidawi@unja.ac.id
}

\begin{abstract}
Abstrak. Sistem pemerintahan yang dipraktekkan diberbagai negara saat ini cenderung mengalami perubahan. Beberapa negara memiliki ciri khas tersendiri dalam penyelenggaraan eksistensi negera. Ciri khas negara tersebut salah satunya adalah dengan memiliki sistem pemerintahan. Adapun Negara Indonesia Secara konstitusional menganut sistem pemerintahan presidensial, sistem pemilu proporsional dan menganut sistem multi partai. Sampai sekarang, pemerintahan demokratis yang dibangun belum stabil, hal ini tidak terlepas dari tidak cocoknya bangunan ketiga sistem tersebut. Rumusan sistem presidensial yang diamanatkan konstitusi ternyata sulit dalam penerapannya, bahkan berjalan kurang efektif apalagi didukung oleh lemahnya performa dan lembaga presiden dalam menjaga stabilitas politik. Dengan demikian perlu desain sistem pemerintahan presidensial yang efektif dengan penataan kembali baik secara institusional maupun non institusional. Tulisan ini merupakan hasil kajian konsep teoritis tentang sistem pemerintahan yang hingga kini masih dipraktekkan di berbagai negara. Metode kajian ini menggunakan metode kualitatif deskriptif dan studi literatur.
\end{abstract}

Kata Kunci: Desain; Sistem Presidensil; Teoritis; Efektif.

Abstract. The system of government that is practiced in various countries now tends to change. Some countries have their own characteristics in the implementation of the country's existence. One of the special characteristics of the country is having a government system. The Indonesian State constitutionally adheres to a presidential government system, a proportional electoral system, and a multi-party system. Until now, the democratic government that was built has not been stable, this is inseparable from the incompatibility of the building of the three systems. The formulation of the presidential system mandated by the constitution turned out to be difficult in its application, even running ineffectively let alone supported by the weak performance and presidential institutions in maintaining political stability. Thus it is necessary to design an effective presidential government system with realignment both institutionally and non-institutionally. This paper is the result of a study of theoretical concepts about the government system which is still practiced in various countries. The method of this study uses descriptive qualitative methods and literature studies.

Keywords: Design, Presidential System, Theoretical, Effective.

\section{PENDAHULUAN}

Kajian tentang desain sistem pemerintahan yang ideal dan efektif seringkali menjadi tema yang cukup menarik untuk dikaji secara lebih mendalam, tentu dalam rangka mewujudkan dan menghadirkan bentuk sistem pemerintahan yang baik (good governance), stabil, ideal dan efektif untuk menopang sistem demokrasi.

Dalam sejarah panjang pemerintahan Indonesia, sempat beberapa kali terjadi perubahan pada sistem pemerintahannya.
Pertama, Pada saat pertama kali negara Republik Indonesia diproklamasikan, republik ini menganut sistem presidensial. Kedua, saat terjadi konferensi meja bundar (KMB) karena ditetapkannya konstitusi Republik Indonesia Serikat (RIS), maka secara otomatis Indonesia berubah bentuk menjadi negara serikat dan menerapkan sistem parlementer pada pemerintahannya. Ketiga, Setelah berlakunya UUDS 1950, Negara Republik Indonesia kembali berbentuk negara kesatuan, dan sistem pemerintahannya masih menggunakan 
sistem parlementer (Isra, 2018, h. 35). Keempat, setelah keluarnya Dekrit Presiden pada 5 Juli 1959, sistem pemerintahan di Indonesia kembali menjadi presidensial. Hal tersebut karena Dekrit Presiden 1959 berisi bahwa UUDS 1950 tidak lagi berlaku dan kembali ke UUD 1945, serta pembubaran konstituante karena gagal membuat konstitusi yang baru.

Akhirnya hingga saat ini sistem pemerintahan Indonesia kembali menjadi presidensial seperti pada waktu pertama Negara Kesatuan Republik Indonesia diproklamasikan. Walaupun begitu ada hal yang berbeda pada UUD 1945 yang diamandemen karena dianggap presiden memiliki kewenangan yang sangat besar sehingga dapat disalahgunakan. Berdasarkan sejarah diatas, mari kita lihat bagaimana hasil dari implementasi sistem pemerintahan presidensil di Indonesia. Pada tahun 19601965 implementasi sistem pemerintahan presidensial dipadukan dengan sitem multipartai terbatas, hanya 10 partai politik. Selanjutnya tahun 1966-1998 penyederhanaan partai politik dilakukan dengan fusi partai, sehingga hanya 3 partai saja yang selalu bertarung dalam setiap Pemilu. Pada era ini implementasi sistem pemerintahan presidensial dipadukan atau disandingkan dengan sistem multipartai sangat terbatas.

Pada masa orde lama dan orde baru, implementasi sistem pemerintahan presidensial berjalan efektif dan stabil karena adanya penyederhanaan pada partai politik, kuatnya karakter kepemimpinan nasional, serta adanya kekuasaan terpusat pada satu tangan oleh presiden yang mengarah pada kekuasaan dominan berada ditangan Presiden yang dilengkapi dengan berbagai hak konstitusional atau hak prerogatif (eksekutif heavy).

Paska reformasi partai politik tumbuh subur, sebagai wujud kebebasan berorganisasi, sehingga sistem kepartaian kembali pada sistem multipartai. Sistem pemerintahan presidensial tidak bisa berjalan sebagaimana mestinya, karena kuatnya parlemen yang didukung partai politik. Partaipartai politik di DPR memainkan peranan, fungsi, dan hak DPR secara maksimal.
Apalagi bila dirunut bahwa antara parlemen dengan presiden sama-sama dipilih oleh rakyat, biasanya akan sama-sama mengklaim mendapatkan legitimasi kuat karena pilihan langsung itu. Juan J. Linz mengatakan sebagai berikut:

But what the most striking is that in a presidential system, the legislators, especially when they represent cohesive, disciplined parties that offer clear ideological and political alternatives, can also claim democratic legitimacy. This claim is thrown into high relief when majority of legislature represent a political option opposed to the one the president represents. Under such circumstances, who has the stronger claim to speak on behalf of the people: the, or the legislative majority that opposes his policies?)( Juan J/Linz \& Lijphart, 1992)

Dari ilustrasi di atas, Juan J. Linz menggambarkan bahwa hubungan antara Presiden dengan legislative akan mengalami problematika karena sama-sama mengklaim bahwa mereka dipilih oleh rakyat. Ini yang kemudian menyulitkan terciptanya checks and balances. Terkait dengan Permasalahan diatas, ada beberapa hal yang perlu kami bahas lebih lanjut antara lain: 1). Bagaimana Penerapan atau Implementasi Sistem Pemerintahan Presidensial di Indonesia Pasca Era Reformasi? 2). Bagaimana Skema Sistem Pemerintahan Presidensial yang Efektif di Indonesia berdasarkan Kajian Teoritis?

Adapun beberapa penelitian terdahulu yang membahas tentang desain sistem pemerintahan presidensial yang efektif diantaranya: 1). Susilo Imam Santosa dan I Ketut Suardita dengan judul desain sistem pemerintahan presidensial yang efektif didalam tulisan tersebut imam santosa dan I Ketut Suardita menyimpulkan bahwasanya sistem pemerintahan presidensial yang efektif itu adalah memperbaiki sistem pemilu dan sistem kepartaian di Indonesia. 2). Zuhdi Arman, Tinjaun terhadap sistem multipartai dalam sistem pemerintahan presidensial di indonesia pada era reformasi. Dalam kesimpulannya, Zuhdi arman mengatakan 
Ada 3 (tiga) hal yang menjadi implikasi penerapan sistem multi partai terhadap relasi eksekutif-legislatif dalam sistem pemerintahan Presidensial di Indonesia pada era reformasi, yaitu: Pertama, banyaknya kepentingan partai politik yang bertentangan dengan kebijakan pemerintah. Kedua, tidak adanya pengaturan koalisi tetap. Ketiga, lemahnya posisi Presiden. Dari penelitian diatas dapat penulis tegaskan yang menjadi perbedaan dari penelitian-penelitian terdahulu dengan penelitian ini adalah penelitian yang terdahulu lebih bersifat umum dan tidak spesifik pada negara indonesia sedangkan penelitian ini lebih spesifik membahas rekayasa sistem pemerintahan presidensial yang efektif di indonesia.

\section{METODE PENELITIAN}

Metode Penelitian yang digunakan dalam penelitian ini adalah kualitatif. Penelitian kualitatif adalah penelitian yang berangkat dari perspektif fokus penelitian yang mengacu pada kualitas makna (Moleong: 2007). Metode pengumpulan data adalah penelitian kepustakaan yang didukung oleh media cetak seperti buku, majalah, surat kabar, jurnal, laporan dari berbagai sumber, dan juga media elektronik, terutama internet di mana data merupakan sumber sekunder. Selain data sekunder diatas penulis juga menggunakan data primer yang didapatkan dari wawancara bersama pihak yang kompeten dalam menjawab persoalan penelitian ini. Setelah didapatkan datanya, maka data-data diatas akan dianalisis dalam kerangka teoritis yang telah ditentukan untuk membuktikan bahwa hipotesis itu akurat dan akhirnya dapat menjawab pertanyaan penelitian.

\section{HASIL DAN PEMBAHASAN}

Indonesia sudah menerapkan sistem presidensial sangat lama namun sistem presidensial yang dilaksanakan nampaknya tidak genuine atau murni hal ini bisa kita lihat dan cermati dari karakteristik parlementer dalam proses legislasi. Meskipun adanya karakteristik parlementer dalam proses legislasi, namun hal tersebut tidak menjadi masalah karena kondisinya masih memungkinkan dan juga dilihat dalam konteks ketatanegaraan hal semacam ini sah- sah saja, asalkan penggabungan sistem pemerintahan tetap dapat menghadirkan pemerintahan yang efektif, akuntabel, dan demokratis. Sistem presidensialisme di Indonesia pada kenyataannya telah dikombinasikan dengan sistem multipartai. Indonesia merupakan negara yang memiliki tingkat kemajemukan masyarakat yang sangat tinggi dan pluralitas sosial yang kompleks. Hal inilah yang menyebabkan Indonesia menggunakan sistem multipartai. Faktor utama adalah kemajemukan masyarakat. Faktor ini yang menyebabkan keniscayaan bagi penerapan sistem multipartai. Sementara kemajemukan masyarakat merupakan sesuatu yang bersifat given dalam struktur masyarakat Indonesia. Faktor kedua, sejarah dan sosiokultural masyarakat, merupakan faktor pendukung bagi terbentuknya sistem multipartai. Multipartai semakin mantap ketika ditopang sistem pemilihan proporsional. Penerapan sistem pemilu proporsional menjadi faktor ketiga bagi terbentuknya multipartai di Indonesia. Ketiga faktor ini merupakan satu kesatuan yang saling berhubungan dan memengaruhi. Pada saat ini terlihat bahwa penerapan presidensialisme yang berkombinasi dengan sistem multipartai dalam beberapa hal masih mengakibatkan pemerintahan kurang efektif.

\section{Sudut Pandang Teori Terhadap Sistem Presidensial.}

Apabila kita runut dari kajian teori kekuasaan, yang kenal dengan teori trias politica yang dikemukakan oleh John Locke. John Locke dalam karya ilmiahnya Two Treatises on Civil Government antara lain menyatakan perlu adanya pembagian kekuasaan atas kekuasaan yang membentuk undang-undang (UU), kekuasaan yang melaksana undang-undang, dan kekuasaan federatif. John Locke merupakan orang yang pertama kali memikirkan perlunya dilakukan pemisahan kekuasaan dalam sistem penyelenggaraan kekuasaan negara.

Menurut John Locke, tahap terbentuknya negara unionis, yaitu perjanjian antar individu untuk membentuk body politics, (negara). Hal itu diperlukan supaya kebebasan dan hak asasi manusia yang satu jangan sampai melanggar kebebasan dan hak 
asasi manusia lainnya, maka mereka bersepakat untuk mengakhiri suatu keadaan alami tersebut dengan membentuk suatu organisasi body politic (negara). Tahap kedua, tahap pactum subyektionis, yaitu para individu menyerahkan hak dan kebebasannya kepada negara, dengan memegang hak-hak asasinya untuk melakukan pengawasan terhadap body politics (negara) tersebut supaya tidak terjadi abuse of power atau penyalahgunaan wewenang (Locke, 2008, h. $1)$.

\section{Berdasarkan Teori kekuasaan diatas, kemudian melahirkan teori sistem} pemerintahan yang pada umumnya dibagi menjadi 2 bentuk. 1). Sistem Parlementer, 2). Sistem Presidensial. Adapun ciri-ciri dari Sistem Parlementer sebagai berikut (Isra, 2013, h. 30) : 1. Adanya parlemen; 2. Eksekutif dibagi menjadi dua bagian; 3. Kepala Negara menunjuk Kepala Pemerintahan; 4. Kepala Pemerintahan menunjuk menteri; 5. Kementrian/pemerintah adalah suatu lembaga kolektif; 6. Menterimenteri biasanya adalah anggota parlemen; 7 . Pemerintah secara politis bertanggung jawab terhadap jalannya persidangan; 8. Kepala pemerintahan dapat memberikan pertimbangan kepada Kepala Negara untuk membubarkan parlemen; 9. Parlemen adalah lembaga tertinggi; 10. Pemerintah tidak secara langsung bertanggung jawab kepada pemilih; 11. Parlemen adalah pusat kekuasaan dalam sistem politik.

Sementara itu ciri-ciri Sistem Presidensial sebagai berikut: 1. Presiden adalah kepala Negara dan kepala pemerintahan; 2. Presiden tidak dipilih oleh legislative tetapi dipilih langsung oleh konstituen; 3. Presiden bukan bagian dari legislative, dan dia tidak boleh berasal dari kantor legislative kecuali melalui proses impeachment secara legal; 4. Presiden tidak bisa membubarkan legislative dan memerintahkan pelaksanaan pemilu (Ball \& Peters, 2000, h. 63).

Dengan ciri-ciri sistem presidensial seperti diatas, maka posisi presiden sangat kuat karena mendapatkan legitimasi dari pemilihnya yang memilih secara langsung. Posisi itu juga membawa hubungan yang seimbang antara presiden dengan legislatif karena tidak bisa saling mengganggu. Presiden, karena tidak dipilih oleh parlemen, maka presiden tidak mempunyai beban moral (hutang budi) kepada parlemen. Sebaliknya, Presiden tidak bisa membubarkan parlemen. Dengan pola hubungan antara presiden dan parlemen yang seperti ini maka pemerintahan akan ideal dan efektif.

\section{Implementasi Sistem Presidensial di Indonesia Pasca Reformasi}

Berdasarkan ciri-ciri sistem presidensial yang ada dalam UUD 1945, maka dapat dikatakan sistem (pemurnian) terutama dengan adanya ketentuan tentang pemilihan presiden dan wakil presiden secara langsung; pemakzulan presiden dan wakil presiden melalui lembaga peradilan; penegasan ketentuan bahwa presiden tidak dapat membubarkan DPR; dan penegasan DPR sebagai pemegang kekuasaan membentuk undang-undang. Terkait dengan masalah lembaga pembentuk undang-undang, DPR bukanlah satu-satunya lembaga yang melakukan pembahasan suatu rancangan undang-undang, akan tetapi masih ada lembaga lain yaitu presiden. Bahwa setiap rancangan undang-undang dibahas bersamasama oleh DPR dan presiden (Lihat isi UUD 1945, Pasal 20: 2), dengan demikian adanya persetujuan bersama memberikan otoritas ganda dalam pembentukan undang-undang. Pola pembahasan demikian menurut Ismail Suny, Moh. Kusnardi dan Harmaily Ibrahim sebagai model legislasi yang dipraktikkan dalam sistem pemerintahan parlementer (Isra, 2010, h. 6).

Jika diletakkan dalam sistem pemerintahan presidensial, maka pelaksanaan sistem pemerintahan presidensial pasca reformasi belum dapat dikatakan sebagai penerapan sistem pemerintahan presidensial secara murni, terutama karena masih adanya karakteristik parlementer dalam proses legislasi. Meskipun adanya karakteristik parlementer dalam proses legislasi, namun hal tersebut tidak menjadi masalah hal itu dikarenakan kondisinya masih memungkinkan demikian, dan juga dilihat dalam konteks ketatanegaraan hal semacam ini sah-sah saja, asalkan penggabungan sistem 
pemerintahan dapat menghadirkan pemerintahan yang ideal, efektif dan demokratis.

Pada saat ini terlihat bahwa penerapan sistem pemerintahan presidensial yang berkombinasi dengan sistem multipartai dalam beberapa hal masih mengakibatkan pemerintahan kurang ideal dan efektif, beberapa bukti antara lain:

Pertama, bahwa penerapan sistem presidensial dalam konteks multipartai (banyak partai) pragmatis atau compromise presidentialism cenderung memunculkan intervensi partai politik terhadap presiden dan sebaliknya presiden cenderung mengakomodasi kepentingan partai politik dalam menyusun kabinet. Pembentukan kabinet yang semula merupakan hak prerogatif presiden, dalam sistem presidensial kompromis ini presiden ikut melibatkan peran partai politik. Implikasi dari pola intervensi dan akomodasi ini menyebabkan model koalisi pendukung pemerintah yang terbangun adalah koalisi yang rapuh. Kerapuhan ikatan koalisi disebabkan partai politik dalam sistem multipartai pada umumnya tidak memiliki kedekatan secara ideologis, dan komposisi partai politik yang berkoalisi cenderung berubah-ubah.

Kedua, dalam hubungan legislatif dan eksekutif, maka kebijakan publik yang diambil eksekutif memang semestinya diawasi legislatif. Namun, dengan tingginya konflik antara legislatif dan eksekutif dalam sistem pemerintahan presidensial yang bersifat kompromis menyebabkan pemerintahan berjalan tidak efektif, bahkan hak angket dan penarikan dukungan selalu menjadi alat bagi partai untuk bernegosiasi dengan seorang Presiden (Yuda. 2010, h. 261). Fenomena ini memiliki kecenderungan yang besar terjadi pada sistem multipartai karena presiden sangat sulit mendapatkan dukungan mayoritas parlemen. Selain itu, polarisasi dan fragmentasi politik di parlemen juga cukup tinggi dalam sistem multipartai.

Ketiga, proses pemberhentian atau penjatuhan presiden dalam sistem pemerintahan parlementer relatif lebih mudah ketimbang dalam sistem presidensial. Presiden dan wakil presiden dalam sistem presidensial tidak bisa di-impeach atau diberhentikan karena alasan politik. Sebuah Impeachment atau pemberhentian Presiden dan wakil presiden dan jabatannya dalam sistem presidensial hanya bisa dilakukan karena alasan pelanggaran hukum lebih spesifik lagi dibatasi pada kasus-kasus tindak pidana tertentu. Prinsip presidensialisme ini berpotensi mengalami reduksi ketika diterapkan di atas struktur politik multipartai yang pragmatis. Pada sistem presidensial kompromis, presiden cenderung dapat diimpeach karena alasan politik. Berdasarkan aspek kompromi eksternal, implementasi kombinasi sistem presidensial dan multipartai dapat diambil kesimpulan mengalami penurunan kualitas serta dalam penerapannya berjalan kurang ideal dan efektif, karena prinsip-prinsip sistem pemerintahan presidensial mengalami reduksi.

\section{Rekayasa Desain Sistem Presidensial di} Indonesia yang Efektif

Berdasarkan Undang-Undang Dasar (UUD) 1945, Negara Indonesia dalam pemerintahannya menggunakan sistem pemerintahan presidensial. Dalam sejarahnya, sistem presidensial di Indonesia sudah ada sejak kemerdekaan. Dari periode ke periode, sampai setelah terjadi amandemen UUD 1945 dan pemilu presiden 2009, dinamika sistem presidensial di Indonesia menunjukkan beberapa perubahan sekaligus beberapa dilema yang dihadapi oleh presiden yang terpilih. Ada tiga desain institusi politik menurut Hanta Yuda yang perlu dirancang dan di tata kembali untuk menuju Sistem Pemerintahan Presidensial yang Efektif (Yuda, 2010, h. 272).

Pertama, Desain Pemilu, pemilu perlu dirancang untuk mendorong penyederhanaan jumlah partai politik di parlemen sekaligus mendukung penguatan sistem pemerintahan presidensial. Dengan meroformasi sistem pemilu, penyederhanaan jumlah partai politik dapat ditempuh melalui beberapa agenda salah satunya rekayasa institusional atau (institutional engineering), antara lain: menerapkan sistem pemilu distrik (plurality/majority system) atau sistem campuran (mixed member proportional), memperkecil besaran daerah pemilihan 
(distric magnitude), menerapkan ambang batas kursi di parlemen (parliamentary threshold) secara konsisten, serta menggabungkan pelaksanaan pemilu legislatif dan pemilu presiden.

Kedua, Desain Institusi Parlemen, rancangan kelembagaan di parlemen diarahkan untuk menyederhanakan dari polarisasi kekuatan politik di parlemen, seperti pengurangan jumlah fraksi dan efektivitas koalisi agar proses-proses politik di parlemen menjadi lebih sederhana dan efisien dalam kerangka checks and balances yang proporsional untuk menghindari terlalu kuatnya lembaga legislatif. Berkaitan dengan hal itu, agenda rekayasa institusional yang perlu dirancang kembali antara lain: penyederhanaan jumlah fraksi di parlemen melalui pengetatan (Administrasi) persyaratan ambang batas (parliamentary threshold) di parlemen dalam pembentukan fraksi, regulasi koalisi parlemen diarahkan ke dua blok politik (pendukung dan oposisi), dan penguatan kelembagaan dan kewenangan Dewan Perwakilan Daerah (DPD) untuk mengimbangi DPR agar fungsi checks and balances tidak hanya terjadi antara presiden dan DPR, tetapi juga antara DPR dan DPD.

Ketiga, Desain Institusi Kepresidenan, desain institusi kepresidenan juga diarahkan untuk memperkuat posisi politik presiden di hadapan parlemen, agar kekuasaan parlemen tidak di atas presiden, tetapi juga menghindari terlalu kuatnya posisi presiden. Selain itu juga diarahkan kabinet solid dan pemerintahan dapat berjalan efektif. Karena itu, ada beberapa agenda rekayasa institusional, antara lain : penataan ulang sistem legislasi, presiden tidak memiliki kekuasaan dalam membentuk undangundang tetapi diberikan hak veto, kejelasan kewenangan wakil presiden dan relasi antara presiden dan wakil presiden, dan aturan larangan rangkap jabatan bagi anggota kabinet.

Demikianlah 3 Desain untuk mencapai Sistem Pemerintahan Presidensil yang Ideal dan Efektif menurut Penulis. Jika ke tiga desain diatas benar-benar bisa di implementasikan maka negara Indonesia akan menjadi salah satu negara yang berhasil dalam menerapkan sistem Presidensil di tengah sistem multi partai.

\section{KESIMPULAN}

Dilihat dari system pemilihan presiden secara langsung di Indonesia, dapat dikatakan bahwa system pemilihan langsung ini memberikan legitimasi yang sangat kuat bagi presiden terpilih karena dipilih secara langsung oleh rakyat. Apabila pemilihan umum untuk memilih anggota dewan, nuansanya lebih diwarnai oleh menonjolnya kontestasi antar partai politik, sementara kalau pemilihan presiden secara langsung, nuansanya lebih mencerminkan kehendak rakyat. Oleh sebab itu, mekanisme dan tatacaranya pun bukan untuk memilih partai politik yang mengusungnya tetapi langsung memilih orangnya, sehingga partai politik hanyalah sebagai kendaraan saja untuk berfungsinya mesin pemilu presiden secara langsung. Dengan legitimasi kuat yang diperoleh dengan pemilihan langsung ini, diharapkan terbentuk kelembagaan presidensial yang juga kuat karena mengakar pada kehendak mayoritas rakyat. Di sisi lain, lembaga presiden juga memerlukan mekanisme untuk mengontrol kekuasaannya sehingga tidak mengarah ke kekuasaan otoriter. Oleh karena itu, mekanisme checks and balances ini perlu agar pemerintahan presidensial bisa berjalan.

Desain sistem pemerintahan presidensial yang Ideal dan efektif adalah dengan mengadakan beberapa agenda perubahan antara lain: Pertama, Desain pemilu, pemilu perlu dirancang untuk mendorong penyederhanaan jumlah partai politik di parlemen yakni dengan menerapkan parliamentary threshold sebesar 5\%; penerapan sistem campuran dalam pemilu (distrik dan proporsional); Kedua, Desain institusi parlemen, rancangan kelembagaan parlemen diarahkan untuk menyederhanakan polarisasi kekuatan politik di parlemen, seperti pengurangan jumlah fraksi dan efektivitas koalisi agar proses-proses politik di parlemen menjadi lebih sederhana. Ketiga, Desain institusi kepresidenan juga diarahkan untuk memperkuat posisi presiden, yakni dengan pembagian kewenangan yang jelas antara presiden dan wakil presiden, dan juga 
pemilihan langsung hanya untuk presiden saja.

Dengan menyadari bahwa system presidensial di Indonesia berbasis multi partai, maka diperlukan mekanisme yang baku yang mempunyai kekuatan hukum kuat untuk menjaga agar pemerintahan presidensial dapat efektif. Ketersediaan UU yang memberi kesempatan pada munculnya koreksi-koreksi kebijakan pemerintah seperti interpelasi, angket maupun gugatan ke pengadilan diperlukan untuk memperkuat system presidensial ini. Di Indonesia UU yang mengatur tentang hak interpelasi, angket maupun gugatan ke pengadilan sudah tersedia. Hanya saja, masih diperlukan penguatan kelembagaan kepresidenan yang berupa restrukturisasi sekretariat presiden yang mengacu pada kebutuhan Presiden untuk menjalankan peran dan fungsinya sebagai kepala pemerintahan.

\section{DAFTAR PUSTAKA}

Ball, Alan R. dan Peters, B. Guy. 2000, Modern Politics and Government, edisi ke 6. Macmillan Press.

Isra, Saldi, 2013, Pergeseran Fungsi Legislasi, Menguatnya Legislasi Parlementer Dalam Sistem Presidensial Indonesia. Jakarta: Rajawali Press. 2018, Sistem Pemerintahan Indonesia: Pergulatan Ketatanegaraan Menuju Sistem Pemerintahan Presidensial. Jakarta: Rajawali Press.

Maleong, J. Lexy. Metodologi Penelitian Kualitatif. Bandung. PT Remaja Rosdakarya, 2004.

Lijphart, Arend (ed). 1992, Parliamentary versus Presidential Government. London: Oxford University Press.

Locke, John. 2008, dalam W. Riawan Tjandra, Hukum Administrasi Negara, Yogyakarta: Universitas Atmajaya.

Sulardi, 2012. Mепији Sistem Pemerintahan Presidensiil Murni. Malang: Setara Press.

UU 23 tahun 2004, Tentang Pemilu Presiden dan Wakil Presiden dan UU 42 tahun 2008, Tentang Pemilu Presiden dan Wakil Presiden.
Wren, J. Thomas \& Price, Terry L. The Values of Presidential Leader. New York: Palgrave Macmilan. 2007.

Yuda, Hanta, 2010, Presidensialisme Setengah Hati, Jakarta: Gramedia Pustaka Utama. 